\title{
Postharvest insect resistance in maize
}

\author{
Laura M. López-Castillo a, Stephanie E. Silva-Fernández a , Robert Winkler ${ }^{\text {b }}$, \\ David J. Bergvinson ', John T. Arnason ${ }^{\mathrm{d}}$, Silverio García-Lara ${ }^{\mathrm{a}, *}$
}

${ }^{a}$ Biotechnology Center, Tecnologico de Monterrey, Campus Monterrey, NL, Mexico

b Biotechnology and Biochemistry Dep., CINVESTAV Unidad Irapuato, Irapuato, Guanajuato, Mexico

${ }^{\mathrm{c}}$ International Crops Research Institute for the Semi-Arid Tropics, ICRISAT, Hyderabad, India

d Department of Biology, University of Ottawa, K1N 6N5, ON, Canada

\section{A R T I C L E I N F O}

\section{Article history:}

Received 17 January 2018

Received in revised form

9 March 2018

Accepted 11 March 2018

\section{Keywords:}

Maize

Pest

Weevil

Grain borer

Insect resistance

Mechanism

Bases

Peroxidase

Phenolic

Response

\begin{abstract}
A B S T R A C T
One of the main challenges for the 21st century is ensuring global food security. Today, maize is the largest staple crop produced worldwide. Postharvest primary insect pests, especially the maize weevil (Sitophilus zeamais) and the large grain borer (Prostephanus truncatus) cause food-grain losses during storage up to $40 \%$ of total production, mainly in developing countries. Alternatives for pest management have been explored, including the implementation of hermetic storage structures and the application of chemical insecticides. Nevertheless, in low-income regions, both strategies are rarely accessible to smallholders. Modern breeding programs have endeavored to develop insect-resistant varieties, which diminish postharvest pest losses. In this review, we report the current status and advances in maize kernel-pest interactions, the bases and mechanisms of kernel resistance and their biotechnological perspectives. We demonstrate that the comprehension of resistance mechanisms has been fundamental for the development of new productive and resistant varieties, representing a sustainable alternative for developing countries. Finally, we analyse the biotechnological perspectives of natural kernel resistance in global food security.
\end{abstract}

(c) 2018 Elsevier Ltd. All rights reserved.

\section{Contents}

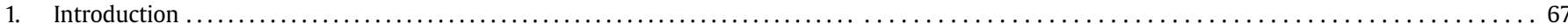

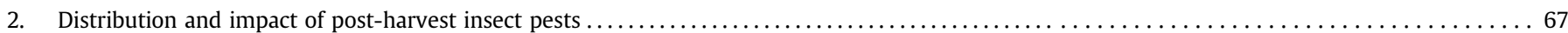

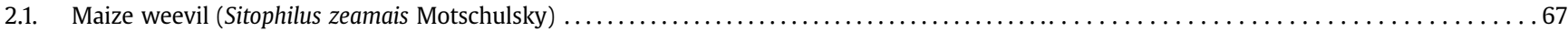

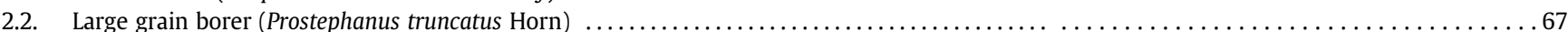

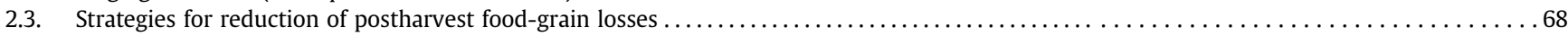

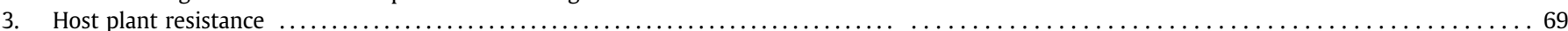

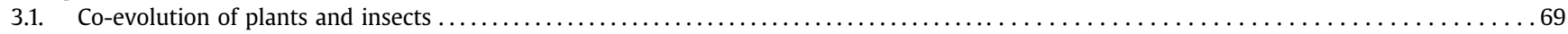

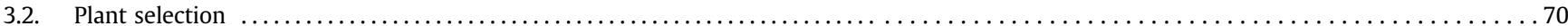

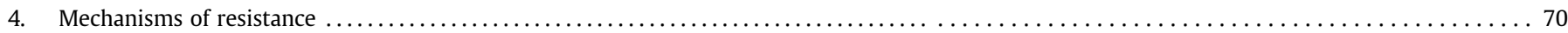

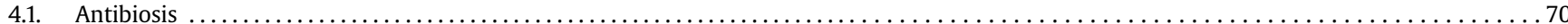

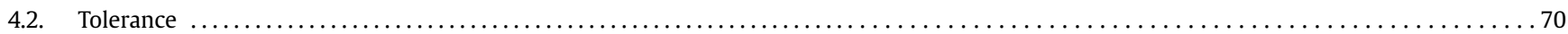

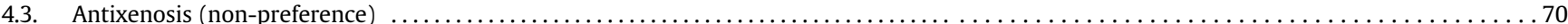

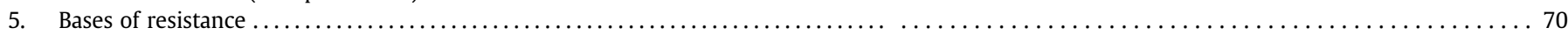

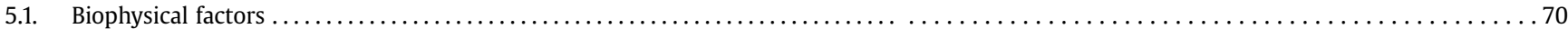

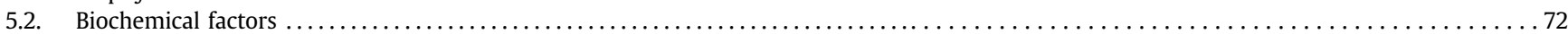

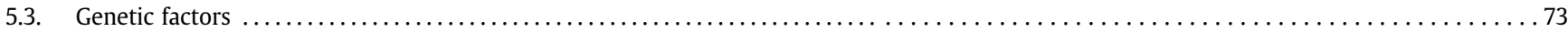

* Corresponding author. Tecnologico de Monterrey, Avenida Eugenio Garza Sada 2501 Sur, CP 64849 Monterrey, Nuevo León, Mexico.

E-mail address: sgarcialara@itesm.mx (S. García-Lara). 


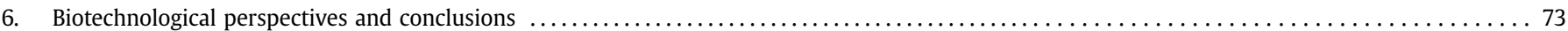

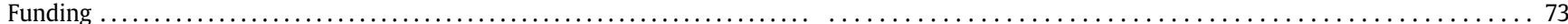

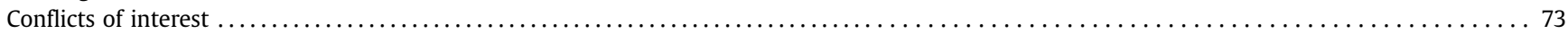

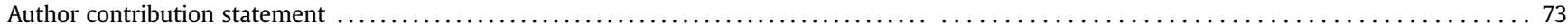

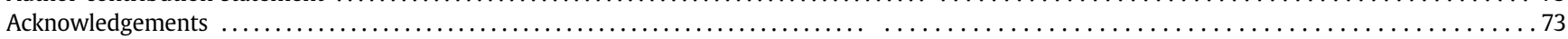

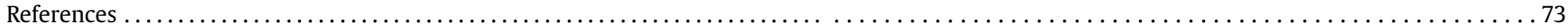

\section{Introduction}

Maize (Zea mays L. (Poaceae)), is the staple crop with the largest production worldwide, with an estimated of 1026 million tons (Cerquiglini et al., 2016). This cereal is the basic food in developing countries in terms of calories and protein intake, ranging from $61 \%$ in Mesoamerica, 45\% in Eastern and Southern Africa, 29\% in the Andean region, to $25 \%$ in West and Central Africa (Shiferaw et al., 2011). In the cited regions, maize is mainly cultivated by smallholder farmers, who take advantage of corn adaptability, high yields and valuable by-products (Rosegrant et al., 2009; Shiferaw et al., 2011). However, biotic and abiotic factors cause losses ranging 30-60\% of global yield (Gitonga et al., 2013; Lesk et al., 2016; Ronald, 2011; Shiferaw et al., 2011). Abiotic stress is mainly caused by extreme environmental conditions, which are enhanced by climate change (Lesk et al., 2016; Ronald, 2011; Shiferaw et al., 2011). Biotic stress caused by diseases, weeds, and insects lead to losses of $54 \%$ of attainable yield in Africa, $48 \%$ in Central and South America, whereas in Asia reached 42\% (Oerke, 2006; Shiferaw et al., 2011). Pre-harvest pests represent an average of $35 \%$ of potential yield loss worldwide (Oerke, 2006; Popp et al., 2013), whereas postharvest losses range between 14 and 36\%. These losses could be observed along the whole food chain, including transport, preprocessing, storage, processing, packaging, marketing and plate waste (Kumar and Kalita, 2017; Popp et al., 2013; Tefera, 2012; Serna-Saldivar and García-Lara, 2016). Postharvest losses caused by insect pests represent $12-36 \%$ of grain weight worldwide (Gitonga et al., 2013; Tefera et al., 2016), affecting mainly low-income developing countries, due to poor postharvest management and inappropriate grain storage conditions (Gitonga et al., 2013; Midega et al., 2016; Tefera et al., 2016; García-Lara and Serna-Saldivar; 2016). Furthermore, significant losses in terms of product quality has been observed when infested kernels by insects were used for manufacture end products such as tortillas (García-Lara et al., 2013a,b).

Management programs have explored diverse alternatives to reduce insect postharvest losses, including chemical crop protection and the implementation of hermetical storage structures (Boyer et al., 2012; García-Lara et al., 2013a,b; Gitonga et al., 2013; Mlambo et al., 2017; Tefera et al., 2011a). International breeding efforts have endeavored to develop high yield insect-resistant maize varieties (Abebe et al., 2009; Tefera et al., 2013, 2016), using maize landraces as natural sources of resistance, which are also adapted to the farming conditions of the target regions. (Arnason et al., 1994; Abebe et al., 2009; García-Lara and Bergvinson, 2013; Midega et al., 2016; Mikami et al., 2012; Tefera et al., 2016). Thus, the knowledge of the mechanisms and molecular bases of the natural resistance is crucial to the identification of resistance traits, which can be used in high-yield insect-resistant varieties. In this review, we discuss the current knowledge about the natural resistance to main storage pests in maize.

\section{Distribution and impact of post-harvest insect pests}

Postharvest maize insect pests include many species from the orders Coleoptera and Lepidoptera, which are distributed worldwide, causing yield and quality losses of grains and by-products, with important economic repercussions (García-Lara and Bergvinson, 2014; Sallam, 1999). However, most of the insect postharvest losses are caused by populations of a single pest, depending of the region and the agroecology, as observed in Table 1. Species such as Sitophilus zeamais, Prostephanus truncatus, Sitotroga cerealella, Rhyzopertha dominica and Tribolium castaneum are considered major pests and are a serious concern in global agriculture (CABI, 2017; García-Lara and Bergvinson, 2014; Gitonga et al., 2013; Mohandass et al., 2007; Sallam; 1999; Tefera et al., 2016). In this review we will focus mainly in two species: Sitophilus zeamais and Prostephanus truncatus.

\subsection{Maize weevil (Sitophilus zeamais Motschulsky)}

Sitophilus zeamais (Coleoptera: Curculionidae) has an ancient origin, about 8.7 million years ago, and has been recognized as predator of modern maize (Corrêa et al., 2016). This pest has been detected in 112 countries worldwide (Fig. 1 and Table 1) (CABI, 2017). Sitophilus zeamais is responsible for $12-36 \%$ grain weight loss worldwide (García-Lara and Bergvinson, 2014; Gitonga et al., 2013; Tefera et al., 2016), reaching $65-80 \%$ in vulnerable zones from tropical and subtropical regions. In western Kenya, $67 \%$ of farmers reported very severe losses caused by this pest (Midega et al., 2016), whereas in Ethiopia losses reached 80\% (Sori and Ayana, 2012). These scenarios lead to extreme food insecurity and poverty in vulnerable regions (Abass et al., 2014; Affognon et al., 2015; Kumar and Kalita, 2017).

\subsection{Large grain borer (Prostephanus truncatus Horn)}

Prostephanus truncatus (Coleoptera: Bostrichidae) is a pest originated in meso-America and accidentally introduced to Africa in the late 1970s (Hodges, 1986). This pest has been detected in tropical and subtropical regions in 26 countries (Table 1 and Fig. 1) (APHLIS, 2017; CABI, 2017; EPPO, 2017). P. truncatus has an enormous impact on the agriculture due to its voracious behavior (Abass et al., 2014; García-Lara and Bergvinson, 2013; Midega et al., 2016). In Latin America, losses caused by this pest can be as high as 50-80\% (García-Lara and Bergvinson, 2013; Kumar and Kalita, 2017). In Western Kenya, 84\% of farmers experienced severe losses in stored maize caused by P. truncatus (Midega et al., 2016), while in Tanzania these losses reached 56.7\% (Abass et al., 2014). Thus, this pest is also a major concern in food security of tropical and dry regions. 
Table 1

Geographical distribution of economically important postharvest insect pests.

\begin{tabular}{|c|c|c|}
\hline Species & Distribution & References \\
\hline Sitophilus oryzae & Warm, tropical and temperate regions worldwide & $\begin{array}{l}\text { Sallam, 1999; Mason and McDonough } \\
\text { 2012; CABI, 2017; EPPO, } 2017\end{array}$ \\
\hline $\begin{array}{l}\text { Sitophilus } \\
\quad \text { zeamais }\end{array}$ & Warm and tropical regions worldwide & $\begin{array}{l}\text { Sallam, 1999; Mason and McDonough, } \\
\text { 2012; CABI, 2017; EPPO, } 2017\end{array}$ \\
\hline $\begin{array}{l}\text { Sitophilus } \\
\text { granarius }\end{array}$ & Temperate regions in Asia, Africa, North and South America, Europe and Australia & $\begin{array}{l}\text { Sallam, 1999; Mason and McDonough, } \\
\text { 2012; CABI, 2017; EPPO, } 2017\end{array}$ \\
\hline $\begin{array}{l}\text { Tribolium } \\
\quad \text { castaneum }\end{array}$ & Tropical and subtropical regions worldwide. Secondary pest. & Sallam, 1999 \\
\hline $\begin{array}{l}\text { Tribolium } \\
\text { confusum }\end{array}$ & Tropical and subtropical regions worldwide. Secondary pest. & Sallam, 1999 \\
\hline Tenebrio molitor & Worldwide & Sallam, 1999 \\
\hline $\begin{array}{l}\text { Rhyzopertha } \\
\text { dominica }\end{array}$ & Tropical and temperate regions worldwide & $\begin{array}{l}\text { Sallam, 1999; Mason and McDonough, } \\
\text { 2012; CABI, } 2017\end{array}$ \\
\hline $\begin{array}{l}\text { Prostephanus } \\
\quad \text { truncatus }\end{array}$ & $\begin{array}{l}\text { Southern USA, Mexico, Central and South America, Africa, Italy. Categorized as quarantine pest in Israel } \\
\text { (2009), Jordan (2007) and New Zealand (2000) }\end{array}$ & $\begin{array}{l}\text { Sallam, 1999; CABI, 2017; APHLIS, 2017; } \\
\text { EPPO, } 2017\end{array}$ \\
\hline $\begin{array}{l}\text { Trogoderma } \\
\text { granarium }\end{array}$ & Temperate regions in South Asia, Africa, former USSR and Spain & Sallam, 1999; CABI, 2017; EPPO, 2017 \\
\hline $\begin{array}{l}\text { Tenebroides } \\
\text { mauritanicus }\end{array}$ & Worldwide. Categorized as quarantine pest in Jordan (2007) & Sallam, 1999; EPPO, 2017 \\
\hline Ephestia cautella & Tropical and subtropical regions worldwide & Sallam, 1999 \\
\hline $\begin{array}{l}\text { Plodia } \\
\quad \text { interpunctella }\end{array}$ & Tropical, subtropical and temperate regions worldwide & Mohandass et al., 2007; Sallam, 1999 \\
\hline $\begin{array}{l}\text { Sitotroga } \\
\quad \text { cerealella }\end{array}$ & Worldwide & Sallam, 1999; CABI, 2017; EPPO, 2017 \\
\hline $\begin{array}{l}\text { Cryptolestes } \\
\text { ferrugineus }\end{array}$ & Worldwide. Categorized as quarantine pest in Jordan (2007) & Mason and McDonough, 2012; EPPO, 2017 \\
\hline
\end{tabular}

\subsection{Strategies for reduction of postharvest food-grain losses}

Integrated pest management programs have explored diverse alternatives to reduce pest postharvest losses, considering the taxonomy, behavior, ecology and biology of the insects and the effective use of monitoring and management tools (Trematerra, 2013). Chemical protection of stored crops has been successfully used to control insect populations, being phosphine the most widely used insecticide (Boyer et al., 2012). However, this strategy have demonstrated hazardous effects to the environment and toxic effects on human and animal health (Boyer et al., 2012; Bumbrah et al., 2012). Besides pesticide toxicity, development of insecticide resistance has been recorded for at least 28 species (Boyer et al., 2012), such as phosphine-resistant populations of Rhyzopertha dominica in Australia (Collins et al., 2017) or pyrethroid-resistant populations of Sitophilus zeamais in Brazil (Corrêa et al., 2011). Thus, it is necessary to explore less toxic and more sustainable alternatives (García-Lara and Serna-Saldivar, 2016).

Hermetic storage structures, including metal silos and portable hermetic bags have been successfully tested under laboratory conditions against diverse pests, including S. zeamais, P. truncatus and S. cerealella (García-Lara et al., 2013a,b; Tefera et al., 2011). Consequently, these structures were tested at field-scale in vulnerable regions, with successful results (Gitonga et al., 2013; Ng'ang'a et al., 2016). In Kenya, the usage of metal silos and super grain bags lead to reduction of losses caused by $S$. zeamais and P. truncatus to less than 5\% (De Groote et al., 2013). However, the associated costs are often unaffordable to low-income farmers (Midega et al., 2016).

In vulnerable regions, farmers have explored more accessible alternatives, such as the application of ground powders from repellent native plants to stored kernels (Midega et al., 2016) and the use of local varieties with some degree of natural resistance. Native maize landraces have been identified as some of the best natural sources of resistance, leading to loss reduction to less than $10 \%$ without cost increment (Daiki et al., 2017; García-Lara and Bergvinson, 2013; Mwololo et al., 2012). However, their yield is often very low. International breeding programs have therefore considered native landraces for the development of high yield genotypes with insect resistance (Abebe et al., 2009; Tefera et al., 2016). Population 84 is an example of an insect-resistant genotype, derived from 20 Caribbean accessions with high resistance to S. zeamais and moderate resistance to P. truncatus (Bergvinson and García-Lara., 2011; García-Lara et al., 2004, 2007). This genotype displayed loss reduction to $30 \%$ of grain weight loss caused by $P$. truncatus infestation in comparison with a susceptible (Bergvinson and García-Lara., 2011). For S. zeamais, loss reduction reached up 75\% of grain weight loss in comparison with a susceptible genotype (García-Lara et al., 2007). Thus, the development of insect-resistant genotypes would be a sustainable alternative for pest control.

Additionally, biological control strategies based on pest/predator or pest/parasitic species have been tested for several pests, including S. zeamais and P. truncatus (Schöller and Flinn, 2000). Parasitic species, such as Lariophagus distinguendus have demonstrated high potential for S. zeamais control, leading to population reduction between 34 and $74 \%$ in bulk maize and $81 \%$ in bag stored maize (Adarkwah et al., 2012). In Kenya, interaction between P.truncatus and Teretrius nigrescens (predator) leaded to reduction of $84 \%$ of the P. truncatus population in a time lapse of 5 years (Hill et al., 2003). In addition, combination of insect-resistant genotypes and Teretrius nigrescens displayed synergistic effects on P. truncatus control, leading to adult progeny reduction of $80 \%$, whereas grain weight losses were diminished $80 \%$ in 28 weeks (Bergvinson and García-Lara, 2011).

Transgenic avidin maize was considered as a possible alternative to reduce insect postharvest losses. This GMO was tested at laboratory scale, showing demonstrated toxic effects against diverse storage pests, including S. zeamais and Sitotroga cerealella. However, this technology is not applicable to P. truncatus, which displayed tolerance to avidin (Kramer et al., 2000). Moreover, the development and application of GMO has been a serious concern in the last years, due to rigid regulations and low social acceptance (Araki and Ishii, 2015; Azadi et al., 2017).

Thus, the identification of resistance traits in natural sources is crucial to the development of new varieties adapted to smallholder 


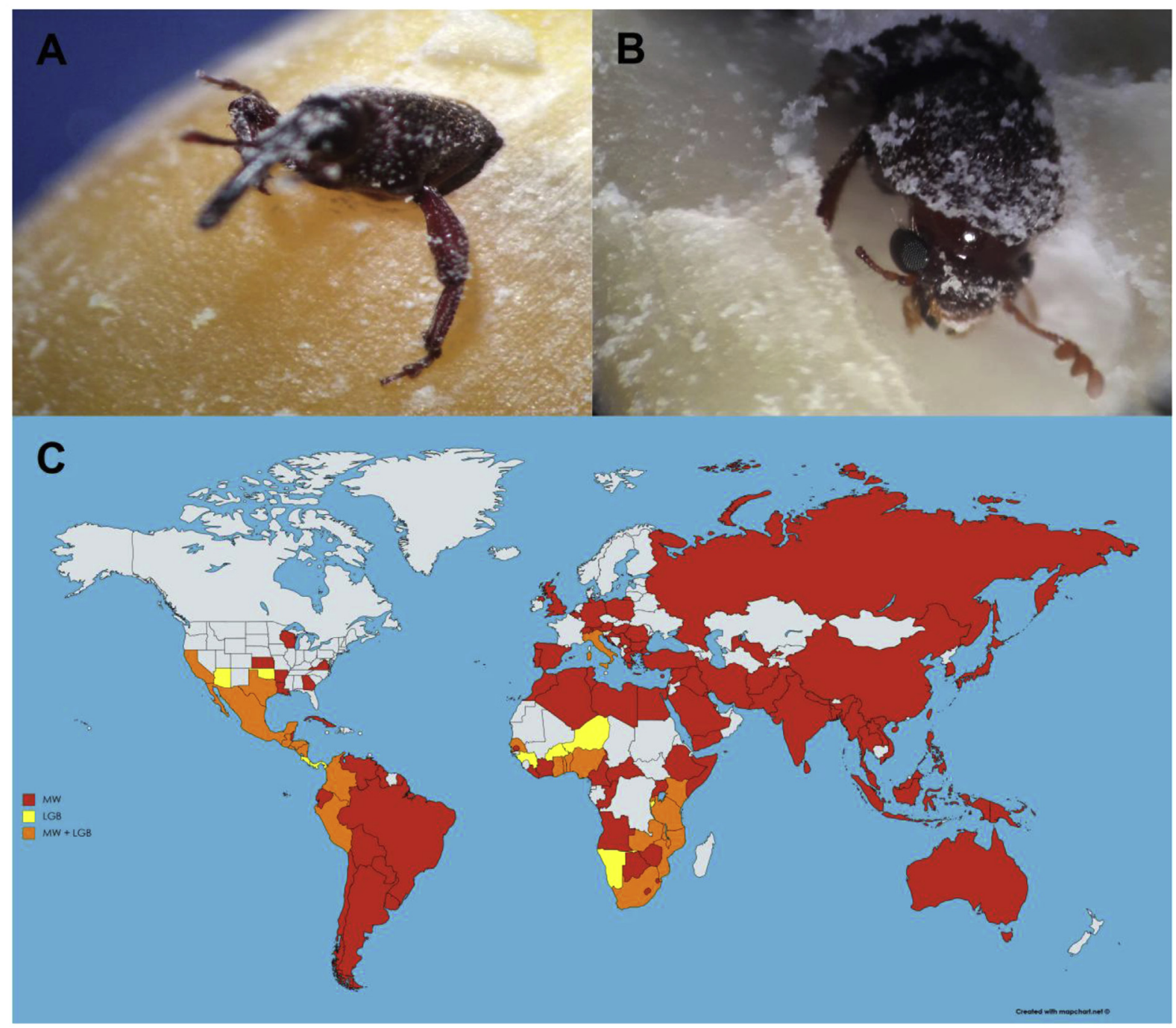

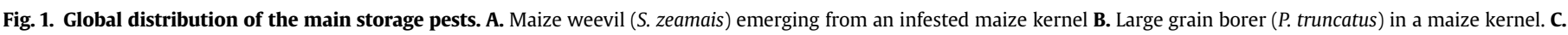

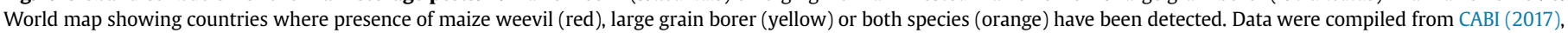
EPPO (2017) and APHLIS (2017) databases. Map was created using the web tool mapchart in the website https://mapchart.net/.

requirements, with the aim to contribute substantially to the assessment of food security of vulnerable regions.

\section{Host plant resistance}

In terms of plant and insect interactions, host plant resistance has been defined as the property by which plant species avoid, tolerate or recover from injury by insect populations, reducing their successful use for insect feeding and/or reproduction (Beck, 1965; Sharma and Ortiz, 2002; Tefera et al., 2016; Thomas and Waage, 1996). This response is determined by heritable plant characters and physicochemical characteristics, which influence insect behavior and biology (Bruce, 2015; Sharma and Ortiz, 2002; Tefera et al., 2016). Plant species could be divided in host and non-host plants. Host plants offer propitious conditions for insect feeding and reproduction, whereas non-host plant do not support insect feeding and/or reproduction (Bruce, 2015). Host plant response could be manifested as immunity (when the plant is not affected by the insect under any condition) high resistance, moderate resistance, low resistance and susceptibility, depending on the impact of insect damage (Beck, 1965; Wiseman, 1985). In maize kernels, host resistance against $S$. zeamais and $P$. truncatus has been observed in several landraces (Mwololo et al., 2012; García-Lara and Bergvinson, 2013). This resistance is influenced by biophysical, biochemical and genetic factors, including kernel hardness, pericarp thickness/thougness, phenolic compounds, enzymes and structural components of the kernel (Akpodiete et al., 2015; GarcíaLara et al., 2004, 2007; López-Castillo et al., 2018; Saulnier and Thibault, 1999; Sen et al., 1994). The level of resistance is often assessed by the Dobie Index of susceptibility, which defines a cultivar as highly resistant, moderately resistant or susceptible (Demissie et al., 2015; Dobie, 1974; García-Lara et al., 2007). From an evolutionary perspective, resistance traits are influenced by plant and insect coevolution and/or artificial plant selection (Sharma and Ortiz, 2002; Simms and Fritz, 1990).

\subsection{Co-evolution of plants and insects}

According to the "classic theory", proposed by Ehrlich and Raven (1964), coevolution is a dynamic process whereby plant and insect 
species exhibit reciprocal selective pressure (Agosta, 2006; Ehrlich and Raven, 1964; Jermy, 1984). Along this evolutionary process, insects diversify their feeding habits and behaviors, whereas plants develop defense strategies against insect herbivory, leading to plant and insect diversification (Ehrlich and Raven, 1964; Hogenhout and Bos, 2011; Jermy, 1984; Rausher, 2001; Thompson, 1999). Plant defense strategies are based on physical barriers, constitutive chemical defenses and indirect inducible defenses including volatiles (Ehrlich and Raven, 1964; Hogenhout and Bos, 2011). In the model of kernel-pest interactions, development of maize landraces resistant to insect pests is a good example of co-evolution. During this process (assisted by artificial plant selection), insect pressure induces the development of resistance factors, which are manifested by the bioaccumulation of insect-deterrent compounds, the development of physical barriers and genotypical modifications (Classen et al., 1990; García-Lara and Bergvinson, 2013; IgnjatovićMicić et al., 2013; Serratos et al., 1987; Tamiru et al., 2015). However, insect pressure is often caused by diverse species, and resistance could be broken by the introduction of new colonizing species, as the case of $P$. truncatus in Africa (Hodges, 1986; BosquePérez and Buddenhagen, 1992). Insect survival is also influenced by their sophisticated host selection strategies, mediated by olfactory recognition of semiochemicals coming from adult-infested kernels of the same species and attractant or repellent compounds from the kernel (Danho et al., 2015; Piesik and Wenda-Piesik, 2015; Trematerra et al., 2007, 2013). The knowledge of co-evolution of kernels and insects is important to the understanding of host plant response and to the development of successful breeding programs, considering the agroecological conditions, including the interaction with predator species (Tefera et al., 2016; Bosque-Pérez and Buddenhagen, 1992). Breeding strategies based in co-evolutionary mechanisms, such as the high-dose/refuge strategy have been implemented to delay evolution of insect virulence, and the consequent loss of plant resistance (Rausher, 2001; Lamb et al., 2016). In brief, this strategy consists in the interspersion of susceptible (refuge) plants in a resistant cultivar. Numerous insects will emerge from refuge plants, whereas few resistant insects are expected, preventing the production of homozygous insect progeny adapted to the resistant plants (Rausher, 2001). This strategy has contributed to effective pest control, as observed in the interaction between Bt corn and various pests, including the European corn borer, Ostrinia nubilalis, the southwestern corn borer, Diatraea grandiosella and the tobacco budworm, Heliothis virescens (Huang et al., 2011). Another successful example has been reported for the resistance of spring wheat (Triticum aestivum, L.) to the wheat midge (Sitodiplosis mosellana) in Canada (Lamb et al., 2016).

\subsection{Plant selection}

Artificial selection started with plant domestication for agricultural purposes. During this process, farmers selected resistant plants, which were able to deal with environmental stress, including insects and diseases (Sharma and Ortiz, 2002; Tefera et al., 2016). Modern breeding strategies for the development of insect-resistant maize genotypes (landraces, recurrent selection populations, hybrids) are based on formal plant selection methods, such as artificial infestation or genetic mediation by biotechnological means (García-Lara and Bergvinson, 2013; Sharma and Ortiz, 2002; Tefera et al., 2011b, 2016).

\section{Mechanisms of resistance}

Host plant resistance to insect pests comprises a wide set of genetically inherent qualities (biophysical and biochemical) manifested by three possible mechanisms: antibiosis, antixenosis and tolerance (Beck, 1965; Smith, 1997; Tefera et al., 2016).

\subsection{Antibiosis}

Antibiosis is a mechanism by which host plant constituents causes adverse effects in the pest life cycle (Derera et al., 2001; Mihm, 1985; Tefera et al., 2016; Wiseman, 1994). It results in reduction in insect fertility and fecundity, delayed development, reduced size and weight, malformations, abnormal behavior and/or death (Wiseman, 1994; Khan, 1997). In maize, antibiosis against S. zeamais and P. truncatus has been found in several maize genotypes and landraces (Derera et al., 2001; Nwosu et al., 2015; GarcíaLara and Bergvinson, 2013). This mechanism has been closely associated to the action of allelochemicals such as phenolic acid amides (Fig. 2) (Sen et al., 1994; Arnason et al., 1997). However, the specific mechanisms and their effects on the insect lifecycle remain unknown.

\subsection{Tolerance}

Tolerance has been defined as the genetic ability of plants to grow, reproduce or repair and recover from insect damage (Wiseman, 1994; Smith, 1997; Tefera et al., 2016). In other words, it works as a compensation mechanism, since it does not prevent pest infestation and damage. In postharvest insect resistance, this mechanism does not occur, considering that stored kernels are dormant structures, with temporary suspension of growth and reduced metabolic activity (Amen, 1968; García-Lara et al., 2003).

\subsection{Antixenosis (non-preference)}

Antixenosis or non-preference is an effect on insect behavior, forcing the selection of alternative hosts (Tefera et al., 2016; Cardona and Sotelo, 2005; Khan, 1997; Wiseman, 1994). Antixenotic factors include physical barriers and phytochemical repellents (Smith, 1997). In kernel-insect interactions, antixenosis is usually manifested through mechanical resistance (Fig. 2) through kernel hardness and pericarp thickness/toughness. Both biophysical traits influence kernel accessibility, limiting insect feeding and oviposition (Arnason et al., 1992, 1994; García-Lara et al., 2004; García-Lara and Bergvinson, 2014).

\section{Bases of resistance}

Insect resistance in maize kernels is based in complex interactions between anatomical, biochemical and genetic factors, as observed in Fig. 2. All these factors are considered as bases of resistance, and may have diverse roles in antibiosis and antixenosis (Bergvinson and García-Lara, 2004; Tefera et al., 2016).

\subsection{Biophysical factors}

Biophysical bases of the resistance against $S$. zeamais and $P$. truncatus are involved in the antixenosis mechanism (Akpodiete et al., 2015; García-Lara and Bergvinson, 2014; Serratos et al., 1987). Anatomical barriers of the kernel, such as the pericarp thickness/ toughness, kernel hardness and endosperm vitreous have been directly correlated with the level of resistance (Akpodiete et al., 2015; Classen et al., 1990; García-Lara et al., 2004; Serratos et al., 1987). Studies performed in QPM varieties concluded that kernel hardness per se is not a sole factor influencing susceptibility to $S$. zeamais infestation (Demissie et al., 2015; Oloyede-Kamiyo and Adetumbi, 2017). Pericarp thickness/toughness is a biophysical trait closely associated with cell wall reinforcement. This reinforcement (Fig. 2A, Table 2) is caused by complex interactions 
A

Structural proteins
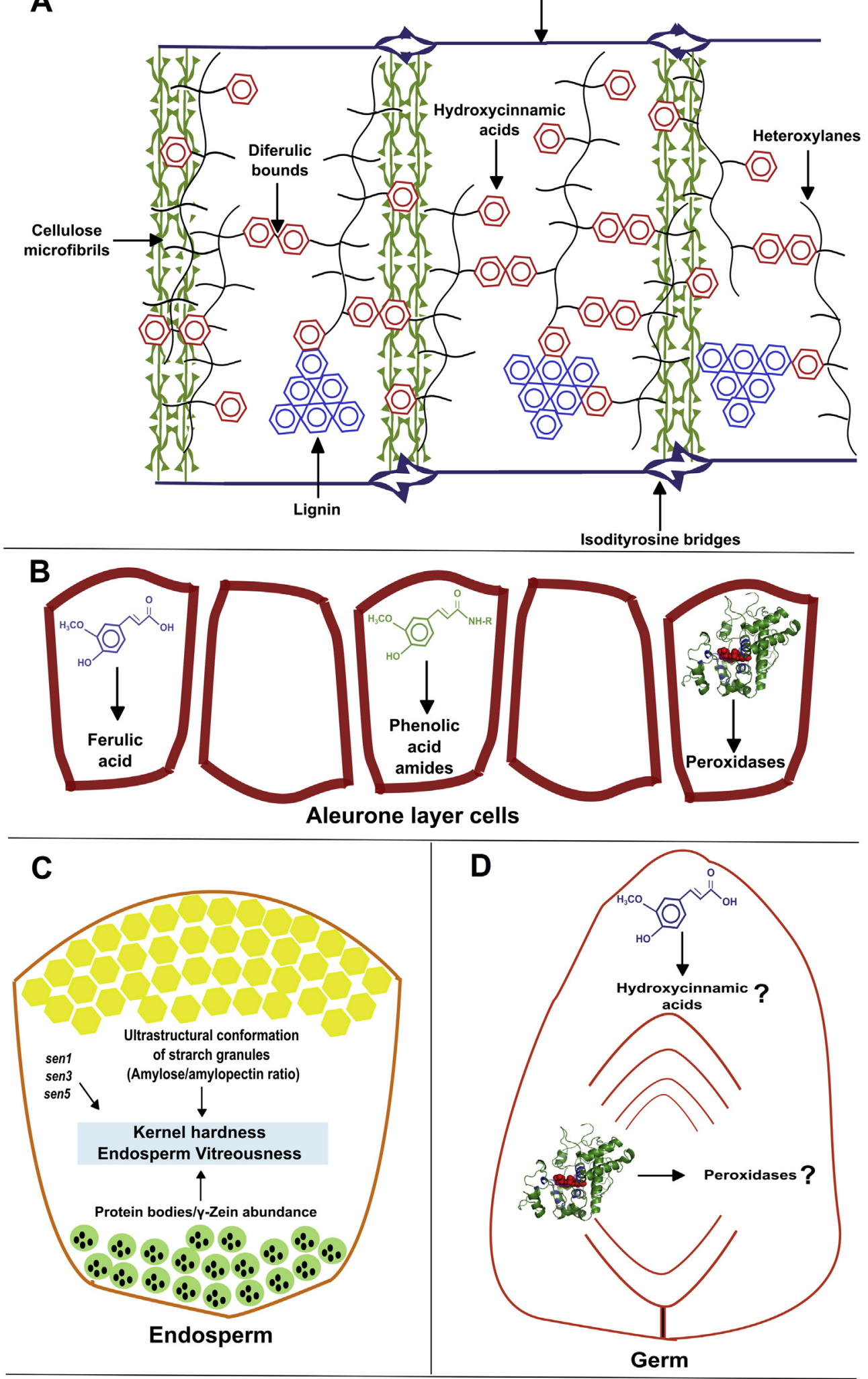

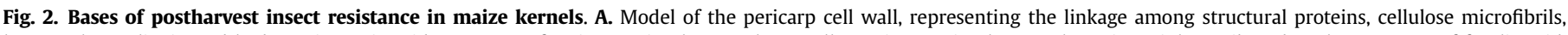

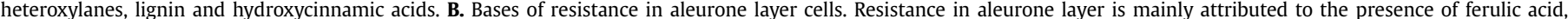

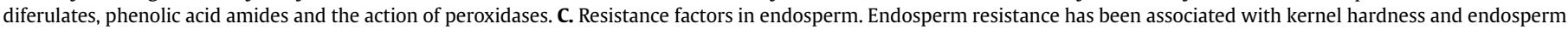

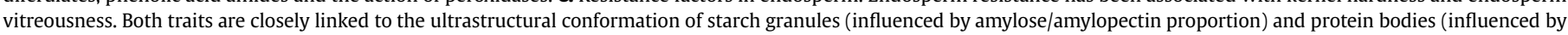

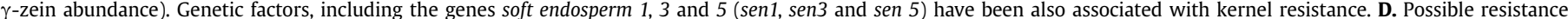

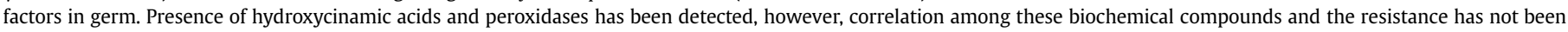
established in this kernel structure. 
Table 2

Principal factors involved in maize kernel postharvest pest resistance.

\begin{tabular}{|c|c|c|}
\hline Bases of resistance & Description & References \\
\hline \multicolumn{3}{|l|}{ a) Anatomical } \\
\hline Kernel hardness & $\begin{array}{l}\text { Implicated in resistance against } P \text {. truncatus and } S \text {. zeamais. Mainly } \\
\text { influenced by the ultrastructural arrangement of starch granules }\end{array}$ & $\begin{array}{l}\text { Demissie et al., 2015; Dombrink-Kurtzman and Knutson, 1997; } \\
\text { García-Lara and Bergvinson, 2014; Gaytán-Martínez et al., 2006; } \\
\text { Mwololo et al., 2013; Narváez-González et al., 2006; Siwale et al., } \\
2009\end{array}$ \\
\hline Pericarp thickness/thoughness & $\begin{array}{l}\text { Implicated in resistance against } P \text {. truncatus and } S \text {. zeamais. } \\
\text { Influenced by phytochemical compounds implicated in cell-wall } \\
\text { reinforcement mechanisms. }\end{array}$ & $\begin{array}{l}\text { Classen et al., 1990; García-Lara et al., 2004; Oloyede-Kamiyo and } \\
\text { Adetumbi, 2017; Santiago et al., 2013; Saulnier and Thibault, } 1999\end{array}$ \\
\hline Vitreous endosperm & $\begin{array}{l}\text { Implicated in resistance against } P \text {. truncatus and } S \text {. zeamais. } \\
\text { Influenced by structural arrangement of starch granules and by } \gamma \text { - } \\
\text { zein content. }\end{array}$ & $\begin{array}{l}\text { García-Lara and Bergvinson, 2014; Landry et al., 2004; Mestres and } \\
\text { Matencio, 1996; Narváez-González et al., } 2006\end{array}$ \\
\hline \multicolumn{3}{|l|}{ b) Biochemical } \\
\hline Hydroxycinnamic acids & $\begin{array}{l}\text { Localized in the pericarp and aleurone layer. Implicated in } \\
\text { resistance against } P \text {. truncatus and } S \text {. zeamais. Contribution in } \\
\text { pericarp cell-wall reinforcement. Identified as possible insect } \\
\text { deterrent compounds. }\end{array}$ & $\begin{array}{l}\text { Classen et al., 1990; García-Lara et al., 2004, 2010a,b; Iiyama et al., } \\
\text { 1994; Ndolo et al., 2013; Santiago et al., 2013; Serratos et al., } 1987\end{array}$ \\
\hline $\begin{array}{l}\text { Hydroxyproline-rich } \\
\text { glycoproteins, extensins }\end{array}$ & $\begin{array}{l}\text { Implicated in resistance against S. zeamais. Contribution in pericarp } \\
\text { cell-wall reinforcement. }\end{array}$ & $\begin{array}{l}\text { García-Lara et al., 2004, 2010a,b; Hood et al., 1991; Santiago et al., } \\
2013\end{array}$ \\
\hline Zeins & $\begin{array}{l}\text { Accumulated in endosperm protein bodies. Implicated in kernel } \\
\text { hardness and endosperm vitreousness }\end{array}$ & $\begin{array}{l}\text { Lopes and Larkins, 1993; Mestres and Matencio, 1996; Robutti et al., } \\
1997\end{array}$ \\
\hline Arabinoxylans & $\begin{array}{l}\text { Implicated in resistance against } S \text {. zeamais and } P \text {. truncatus. } \\
\text { Contribution in pericarp cell-wall reinforcement }\end{array}$ & $\begin{array}{l}\text { Arnason et al., 1994; García-Lara et al., 2004; Iiyama et al., 1994; } \\
\text { Santiago et al., 2013; Saulnier and Thibault, } 1999\end{array}$ \\
\hline Peroxidases & $\begin{array}{l}\text { Implicated in resistance against } S \text {. zeamais and } P \text {. truncatus. } \\
\text { Contribution in cell-wall reinforcement by oxidative coupling of } \\
\text { hydroxycinnamic acids. Contribution in antibiosis mechanism } \\
\text { against } S \text {. zeamais }\end{array}$ & $\begin{array}{l}\text { Arnason et al., 1994; Barros-Rios et al., 2015; García-Lara et al., } \\
\text { 2007; Iiyama et al., 1994; López-Castillo et al., } 2018 .\end{array}$ \\
\hline Phenolic acid amides & $\begin{array}{l}\text { Localized in the aleurone layer. Implicated in antibiosis mechanism } \\
\text { by possible inhibition of insect neuron receptors }\end{array}$ & $\begin{array}{l}\text { Arnason et al., 1994; Fixon-Owoo et al., 2003; García-Lara et al., } \\
\text { 2010a,b; Sen et al., } 1994\end{array}$ \\
\hline \multicolumn{3}{|c|}{ 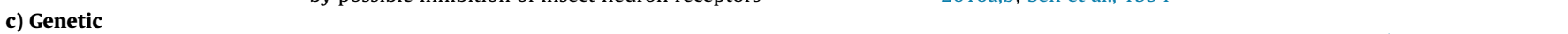 } \\
\hline $\begin{array}{l}\text { Biophysical factors (grain } \\
\text { weight, soft endosperm, } \\
\text { grain dry matter, floury } \\
\text { grain) }\end{array}$ & $\begin{array}{l}\text { Associated with soft endosperm genes (sen } 1, \operatorname{sen} 3 \text { and sen } 5 \text { ) and } \\
\text { QTL grain weight, which co-localized in chromosome } 1.09,2.04 \text {, } \\
3.01 \text {, and } 8.05 \text { with QTL of susceptibility traits. Cellulose syntases } \\
\text { involved in cell wall reinforcement have been also identified. }\end{array}$ & $\begin{array}{l}\text { García-Lara et al., 2009; 2010a,b; 2015; Castro-Álvarez et al., 2015; } \\
\text { Holland et al., 2000; Meyer et al., 2007; Yencho et al., } 2000 .\end{array}$ \\
\hline $\begin{array}{l}\text { Biochemical factors } \\
\text { (peroxidase, pectin } \\
\text { methylesterase and sugar } \\
\text { content) }\end{array}$ & $\begin{array}{l}\text { Related with Peroxidase gene ( } p x 1) \text {, Pectin methylesterase gene } \\
\text { (pme1), and QTL for leaf reductor sugars, which co-localized in } \\
\text { chromosome } 2.05,8.05,10.04 \text { and } 10.07 \text { with susceptibility traits }\end{array}$ & $\begin{array}{l}\text { Davis et al., 1999; García-Lara et al., 2009; 2010a,b; 2015; Holland } \\
\text { et al., 2000; Meyer et al., 2007; Yencho et al., 2000. }\end{array}$ \\
\hline $\begin{array}{l}\text { Response to fungus attack and } \\
\text { other insect pests }\end{array}$ & $\begin{array}{l}\text { Linked with QTL for response to Cercospora zeae-maydis, QTL for } \\
\text { European Corn Borer response, QTL for European Corn Borer } \\
\text { response, QTL for Sugarcane borer response, and QTL for Corn } \\
\text { Earworm response, which co-localized in chromosome } 2.05,4.08 \text {, } \\
8.08,10.04 \text { and } 10.07 \text { with susceptibility traits }\end{array}$ & $\begin{array}{l}\text { Bergvinson and García-Lara, 2006; Castro-Álvarez et al., 2015; } \\
\text { Cardinal and Lee, 2005; García-Lara et al., 2009; 2010a,b; 2015; } \\
\text { Krakowsky et al., 2007; Meyer et al., 2007. }\end{array}$ \\
\hline $\begin{array}{l}\text { Biochemical factors with } \\
\text { undefined function in } \\
\text { resistance }\end{array}$ & $\begin{array}{l}\text { Genes of chalcone synthase, phenylalanine ammonium lyase, } \\
\text { caffeate o-methyltransferase, arginine decarboxylase, ornithine } \\
\text { decarboxylase and spermidine synthase }\end{array}$ & Davis et al., 1999; Meyer et al., 2007; Rodríguez-Kessler et al., 2006 \\
\hline
\end{tabular}

between structural factors (proteins and polysaccharides) and phytochemicals (hydroxycinnamic acids) (Akpodiete et al., 2015; Arnason et al., 1992; García-Lara et al., 2004; Mwololo et al., 2013; Saulnier and Thibault, 1999; Sen et al., 1994). Kernel hardness and endosperm vitreous (Fig. 2C, Table 2) have been associated with the ultrastructural arrangement of starch granules (determined by the amylose/amylopectin ratio) and the content of $\gamma$-zein in protein bodies (Dombrink-Kurtzman and Knutson, 1997; Gaytán-Martínez et al., 2006; Narváez-González et al., 2006).

\subsection{Biochemical factors}

Diverse biochemical factors are involved in antibiosis and antixenosis. Cell-wall reinforcement (Fig. 2A) is a complex antixenotic trait, which involves the crosslinking of proteins (extensins and hydroxyproline-rich glycoproteins) and esterified cell wall hemicellulose (heteroxylans, such as feruloyl and p-coumaroylarabinoxyloses) which surround cellulose microfibrils (García-Lara et al., 2004; Santiago et al., 2013; Saulnier and Thibault, 1999). This process is under metabolic control of esterification reactions (Barros-Rios et al., 2015; García-Lara et al., 2007; Iiyama et al.,
1994). Peroxidase-mediated oxidative coupling of hydroxycinnamic acids form diferulate cross links in hemicelluloses also occur. However, some details about this mechanism remain unknown, such as the identity of specific genes and role of peroxidases implicated in oxidative coupling, although possible candidates have been suggested (López-Castillo et al., 2015; Winkler and GarcíaLara, 2010). In the antibiosis mechanism, phenolic acid amides localized in aleurone layer cells (Fig. 2B), such as diferuloylputrescine and di-p-coumaroylputrescine have been also suggested as insect-deterrent compounds (Arnason et al., 1997; Bily et al., 2003; Sen et al., 1994). However, their mechanism of action is not clear, although possible inhibition of insect neuroreceptors has been suggested (Fixon-Owoo et al., 2003). Recently, peroxidases from the aleurone layer have been suggested as part of the antibiosis mechanism against $S$. zeamais, performing a biochemical response by catalyzing the oxidation of soluble phenolic compounds located at this layer (López-Castillo et al., 2018). Presence of hydroxycinnamic acids and peroxidases has been detected in maize germ (Fig. 2D). However, their function has not been associated yet to insect resistance (García-Lara et al., 2007, 2015). 


\subsection{Genetic factors}

Postharvest insect resistance inheritance has been extensively studied in tropical maize, confirming the polygenic (quantitative) inheritance of resistance, the importance of the pericarp (Tipping et al., 1989), main maternal effects (Serratos et al., 1997) and specific genetic effects for additive and non-additive gene action (Dhliwayo et al., 2005). However, the relatively low heritability of these traits leads to relatively slow progress in trait transference into elite germplasm via phenotypic selection. Therefore, molecular markers are now used to accelerate the transfer of genes or genetic regions associated with resistance in a modern breeding program through marker-assisted selection (MAS). Recent molecular breeding efforts have focused on the identification of genomic areas and genes involved in resistance to the major pests. The principal quantitative trait loci (QTL) and specific associated genes in maize for lepidopteran insect resistance have been elucidated. Loci and genes associated with resistance are clustered in regions co-localized with biochemical resistance factors, as observed in Table 2. Major associations for S. zeamais resistance are located in chromosome 2, 6, 7 and 10, which may be candidate regions for further fine mapping. (Cardinal and Lee, 2005; Castro-Álvarez et al., 2015; García-Lara et al., 2009, 2010a,b; Krakowsky et al., 2007; Yencho et al., 2000). Recently, QTLs for S. zeamais resistance have been detected in an $\mathrm{F}_{2}$ population (GarcíaLara et al., 2009). In addition, when QTLs of phytochemical grain composition were added to the $F_{2}$ map, close association of insect resistance loci with structural cell wall components, key enzymes, and phenolic acid biosynthesis pathways were identified, as observed in Table 2 (García-Lara et al., 2010a,b). Comparing QTL from $F_{2}$ reports on biophysical (García-Lara et al., 2009) and phytochemical (GarcíaLara et al., 2010a,b) resistance parameters, with the RIL mapping population (Castro-Álvarez et al., 2015) there are several common genomic regions. Major QTL areas of cell wall phenolic acids and amides clustered to specific genomic areas that carry genes involved in cell wall biochemistry and phenylpropanoid biosynthesis. These genes include cellulose synthases (Holland et al., 2000), chalcone synthase (Meyer et al., 2007), phenylalanine ammonium lyase, caffeate $O$-methyltransferase genes (Davis et al., 1999), arginine decarboxylase, ornithine decarboxylase and spermidine synthase (Rodríguez-Kessler et al., 2006). QTL mapping is important for the identification of new sources of resistance associated to tissuespecific genes, such as peroxidases (García-Lara et al., 2007; Winkler and García-Lara., 2010; López-Castillo et al., 2015, 2018).

There is clearly a functional relationship between genes and QTL for insect resistance and genes for resistance factors which can now be exploited in the development of resistant maize varieties (Cardinal and Lee, 2005; Krakowsky et al., 2007; Meyer et al., 2007; Castro-Álvarez et al., 2015). Genes and QTLs for disease resistance have now also been associated with insect pest resistance areas in genomic maps. This clustering may be advantageous in the identification of multifunctional markers, which can be used to stack multiple stress resistances into a single variety (Bergvinson and García-Lara, 2006). A disadvantage that needs to be considered is the fact that most of QTLs associated with $S$. zeamais resistance traits show significant QTL $\times E$ interactions. Identification of novel QTL associated with postharvest resistance in maize enables breeders to exploit the genetic variation and increase the efficiency in delivering maize lines resistant to storage pests.

\section{Biotechnological perspectives and conclusions}

Maize kernel resistance to postharvest pests is manifested by antibiosis and antixenosis mechanisms. Both involve complex interactions between biophysical, genetic and biochemical factors, manifested as kernel modifications which lead to limited accessibility or toxicity to the invading pest. Progress has been made that has informed breeding programs and led to the development of resistant cultivars such as the as the Population 84 which have displayed drastic reduction of grain weigh losses caused by S. zeamais (up to $75 \%$ ) and P. truncatus (up to 30\%).

However, our knowledge about natural resistance is still limited. The specific function of biochemical factors, such as peroxidases and phenolic acid amides remains undiscovered. Wider and deeper research in this area is necessary in order to better inform future breeding programs. Modern GMO technologies, such as specific gene editing systems will contribute substantially to elucidate the specific function of resistance genes and the development of new resistance markers. This knowledge will be fundamental in future breeding programs, contributing to reduction of postharvest insect losses of food and global food security, with special interest in vulnerable countries.

\section{Funding}

This research was supported by the Research NutriOmics Chair Funds CAT-005 from Tecnologico de Monterrey, Escuela de Ingeniería y Ciencias.

\section{Conflicts of interest}

The authors declare that the research was conducted in the absence of any commercial or financial relationships that could be considered as a potential conflict of interest.

\section{Author contribution statement}

All authors contributed equally to this work in terms of writing and conception. All authors wrote and reviewed the latest version of this manuscript.

\section{Acknowledgements}

Special thanks to the external reviewers for providing manuscript revision.

\section{References}

Abass, A.B., Ndunguru, G., Mamiro, P., Alenkhe, B., Mlingi, N., Bekunda, M., 2014. Post-harvest food losses in a maize-based farming system of semi-arid savannah area of Tanzania. J. Stored Prod. Res. 57, 49-57. https://doi.org/ 10.1016/j.jspr.2013.12.004.

Abebe, F. Tefera, T., Mugo, S., Beyene, Y, Vidal, S., 2009. Resistance of maize varieties to the maize weevil Sitophilus zeamais (Motsch.) (Coleoptera : Curculionidae). Afr. J. Biotechnol. 8, 5937-5943.

Adarkwah, C., Obeng-Ofori, D., Büttner, C., Reichmuth, C., Schöller, M., 2012. Potential of Lariophagus distinguendus (Förster) (Hymenoptera: Pteromalidae) to suppress the maize weevil Sitophilus zeamais Motschulsky (Coleoptera: Curculionidae) in bagged and bulk stored maize. Biol. Contr. 60, 175-181. https:// doi.org/10.1016/j.biocontrol.2011.11.003.

Affognon, H., Mutungi, C., Sanginga, P., Borgemeister, C., 2015. Unpacking postharvest losses in sub-Saharan Africa: a Meta-Analysis. World Dev. 66, 49-68. https://doi.org/10.1016/j.worlddev.2014.08.002.

Agosta, S.J., 2006. On ecological fitting, plant-insect associations, herbivore host shifts, and host plant selection. Oikos 114, 556-565. https://doi.org/10.1111/ j.2006.0030-1299.15025.x.

Akpodiete, O.N., Lale, N.E.S., Umeozor, O.C., Zakka, U., 2015. Role of physical characteristics of the seed on the stability of resistance of maize varieties to maize weevil (Sitophilus zeamais Motschulsky). IOSR J. Environ. Sci. Toxicol. Food Technol. Ver. II 9, 2319-2399. https://doi.org/10.9790/2402-09226066.

Amen, R.D., 1968. A model of seed dormancy. Bot. Rev. 34, 1-31. https://doi.org/ 10.1007/BF02858619.

APHLIS, 2014. The African Postharvest Losses Information System. https://doi.org/ $10.2788 / 40345$.

Araki, M., Ishii, T., 2015. Towards social acceptance of plant breeding by genome editing. Trends Plant Sci. 20, 145-149. https://doi.org/10.1016/ j.tplants.2015.01.010 
Arnason, J.T., Baum, B., Gale, J., Lambert, J.D.H., Bergvinson, D., Philogène, B.J.R., et al., 1994. Variation in resistance of mexican landraces of maize to maize weevil Sitophilus zeamais, in relation to taxonomic and biochemical parameters. Euphytica 74, 227-236.

Arnason, J.T., Gale, J., Conilh de Beyssac, B., Sen, A., Miller, S.S., Philogène, B.J.R., Lambert, J.D.H., Fulcher, R.G., Serratos, J.A., Mihm, J., 1992. Role of phenolics in resistance of maize grain to the stored grain insects. J. Stored Prod. Res. 28, 119-126.

Arnason, J.T., Conilh de Beyssac, B., Philogène, B.J.R., Bergvinson, D., Serratos, J.A Mihm, J.A., 1997. Mechanism of resistance in maize grain to the maize weevil and the larger grain borer. In: Mihm, J.A. (Ed.), Insect Resistance Maize: Recent Advances and Utilization. CIMMYT, Mexico D.F., Mexico proceeding of an international symposium held at CIMMYT.

Azadi, H., Taube, F., Taheri, F., 2017. Co-existence of GM, conventional and organic crops in developing countries: main debates and concerns. Crit. Rev. Food Sci. Nutr. 8398, 1-12. https://doi.org/10.1080/10408398.2017.1322553.

Barros-Rios, J., Santiago, R., Jung, H.J.G., Malvar, R.A., 2015. Covalent cross-linking of cell-wall polysaccharides through esterified diferulates as a maize resistance mechanism against corn borers. J. Agric. Food Chem. 63, 2206-2214. https:// doi.org/10.1021/jf505341d.

Beck, S.W., 1965. Resistance of plants to insects. Annu. Rev. Entomol. 10, 207-232. Available at: http://www.annualreviews.org/doi/pdf/10.1146/annurev.en.10. 010165.001231.

Bergvinson, D., García-Lara, S., 2004. Genetic approaches to reducing losses of stored grain to insects and diseases. Curr. Opin. Plant Biol. 7, 480-485. https:// doi.org/10.1016/j.pbi.2004.05.001.

Bergvinson, D.J., García-Lara, S., 2006. Consensus mapping for field and storage pest resistance in tropical maize. In: Higman, S. (Ed.), International Plant Breeding Symposium, Mexico City. CIMMYT, Mexico, D.F, 20-25 Aug. 2006.

Bergvinson, D.J., García-Lara, S., 2011. Synergistic effects of insect-resistant maize and Teretrius nigrescens on the reduction of grain losses caused by Prostephanus truncatus (Horn.). J. Stored Prod. Res. 47, 95-100. https://doi.org/10.1016/ j.jspr.2011.01.003.

Bily, A.C., Reid, L.M., Taylor, J.H., Johnston, D., Malouin, C., Burt, A.J., et al., 2003. Dehydrodimers of ferulic acid in maize grain pericarp and aleurone: resistance factors to Fusarium graminearum. Phytopathology 93, 712-719. https://doi.org/ 10.1094/PHYTO.2003.93.6.712.

Bosque-Pérez, N.A., Buddenhagen, I.W., 1992. The development of host-plant resistance to insect pests: outlook for the tropics. In: Menken, S.B.J., Visser, J.H., Harrewijn, P. (Eds.), Proceedings of the 8th International Symposium on Insect-plant Relationships. Springer Netherlands, Dordrecht, pp. 235-249. https://doi.org/10.1007/978-94-011-1654-1_74.

Boyer, S., Zhang, H., Lempérière, G., 2012. A review of control methods and resistance mechanisms in stored-product insects. Bull. Entomol. Res. 102, 213-229. https://doi.org/10.1017/S0007485311000654.

Bruce, T.J.A., 2015. Interplay between insects and plants: dynamic and complex interactions that have coevolved over millions of years but act in milliseconds. J. Exp. Bot. 66, 455-465. https://doi.org/10.1093/jxb/eru391.

Bumbrah, G.S., Krishan, K., Kanchan, T., Sharma, M., Sodhi, G.S., 2012. Phosphide poisoning: a review of literature. Forensic Sci. Int. 214, 1-6. https://doi.org/ 10.1016/j.forsciint.2011.06.018.

CABI, 2017. Sitophilus zeamais. In: Invasive Species Compendium. CAB International, Wallingford, UK. www.cabi.org/isc.

Cardinal, A.J., Lee, M., 2005. Genetic relationships between resistance to stalktunneling by the European corn borer and cell-wall components in maize population B73xB52. Theor. Appl. Genet. 111, 1-7.

Cardona, C., Sotelo, G., 2005. Mecanismos de resistencia a insectos. Naturaleza e importancia en la formulación de estrategias de mejoramiento para incorporar resistencia al salivazo en Bracharia. Pasturas Tropicales 27 (2), 2-11.

Castro-Álvarez, F.F., William, M., Bergvinson, D.J., García-Lara, S., 2015. Genetic mapping of QTL for maize weevil resistance in a RIL population of tropical maize. Theor. Appl. Genet. 128 (3), 411-419. https://doi.org/10.1007/s00122014-2440-6.

Cerquiglini, C., Claro, J., Giusti, A.M., Karumathy, G., Mancini, D., Marocco, E., et al., 2016. Food outlook june 2016. Food Agric. Organ. United Nations 14. Available at: http://www.fao.org/3/a-i5703e.pdf.

Classen, D., Arnason, J.T., Serratos, J.A., Lambert, J.D.H., Nozzolillo, C., Phylogène, B.J.R., 1990. Correlation of phenolic acid content of maize to resistance to Sitophilus zeamais, the maize weevil, in CIMMYT's Collections. J. Chem. Ecol. 16, 301-315.

Collins, P.J., Falk, M.G., Nayak, M.K., Emery, R.N., Holloway, J.C., 2017. Monitoring resistance to phosphine in the lesser grain borer, Rhyzopertha Dominica, in Australia: a national analysis of trends, storage types and geography in relation to resistance detections. J. Stored Prod. Res. 70, 25-36. https://doi.org/10.1016/ j.jspr.2016.10.006.

Corrêa, A.S., Pereira, E.J.G., Cordeiro, E.M.G., Braga, L.S., Guedes, R.N.C., 2011 Insecticide resistance, mixture potentiation and fitness in populations of the maize weevil (Sitophilus zeamais). Crop Protect. 30, 1655-1666. https://doi.org/ 10.1016/j.cropro.2011.08.022.

Corrêa, A.S., Vinson, C.C., Braga, L.S., Guedes, R.N.C., de Oliveira, L.O., 2016. Ancient origin and recent range expansion of the maize weevil Sitophilus zeamais, and its genealogical relationship to the rice weevil S. oryzae. Bull. Entomol. Res. 1-12. https://doi.org/10.1017/S0007485316000687.

Daiki, M., Tomoka, Y., Chandiona, M., Ephantus, N.B., Rodney, L.G., Jiwan, P.P., et al., 2017. Superiority of Malawian orange local maize variety in nutrients, cookability and storability. Afr. J. Agric. Res. 12, 1618-1628. https://doi.org/ 10.5897/AJAR2017.12138.

Danho, M., Alabi, T., Haubruge, E., 2015. Oviposition strategy of Sitophilus zeamais Motsch. (Coleoptera: Curculionidae) in relation to conspecific infestation. Afr. J. Agric. Res. 10, 301-307. https://doi.org/10.5897/AJAR2013.8304.

Davis, G.L. McMullen, M.D., Baysdorfer, C., Musket, T., Grant, D., Staebell, M., Xu, G. Polacco, M., Koster, L., Melia-Hancock, S., Houchins, K., Chao, S., Coe, E.H., 1999 A maize map standard with sequenced core markers, grass genome reference points and 932 expressed sequence tagged sites (ESTs) in a 1736-locus map. Genetics 152, 1137-1172.

De Groote, H., Kimenju, S.C., Likhayo, P., Kanampiu, F., Tefera, T., Hellin, J., 2013. Effectiveness of hermetic systems in controlling maize storage pests in Kenya. J. Stored Prod. Res. 53, 27-36. https://doi.org/10.1016/j.jspr.2013.01.001.

Demissie, G., Tilahun, B., Dida, M., Teklewold, A., Wegary, D., 2015. Evaluation of quality protein maize inbred lines for resistance to maize weevil Sitophilus zeamais (Coleoptera: curculionidae) and other important agronomic traits. Euphytica 205, 137-150. https://doi.org/10.1007/s10681-015-1412-5.

Derera, J., Pixley, K.V., Denash Giga, P., 2001. Resistance of maize to the maize weevil: I. Antibiosis. Afr. Crop Sci. J. 9, 431-440.

Dhliwayo, T., Pixley, K., Kazembe, V., 2005. Combining ability for resistance to maize weevil among 14 southern African maiz inbred lines. J Agri Crop Sci 45 662-667.

Dobie, P., 1974. The laboratory assessment of the inherent susceptibility of maize varieties to post-harvest infestation by Sitophilus zeamais Motsch. (Coleoptera, Curculioniadae). J. Stored Prod. Res. 10, 183-197. https://doi.org/10.1016/0022 474X(74)90006-X.

Dombrink-Kurtzman, M.A., Knutson, C.A., 1997. A study of maize endosperm hardness in relation to amylose content and susceptibility to damage. Cereal Chem. 74, 776-780. https://doi.org/10.1094/CCHEM.1997.74.6.776.

Ehrlich, P.R., Raven, P.H., 1964. Butterflies and plants: a study in coevolution. Source Evol. 18, 586-608. https://doi.org/10.2307/2406212.

EPPO, 2017. EPPO Global Database (available online). https://gd.eppo.int.

Fixon-Owoo, S., Levasseur, F., Williams, K., Sabado, T.N., Lowe, M., Klose, M., et al. 2003. Preparation and biological assessment of hydroxycinnamic acid amides of polyamines. Phytochemistry 63, 315-334. https://doi.org/10.1016/S00319422(03)00133-X.

García-Lara, S., Arnason, J.T., Díaz-Pontones, D., Gonzalez, E., Bergvinson, D.J., 2007. Soluble peroxidase activity in maize endosperm associated with maize weevil resistance. Crop Sci. 47, 1125-1130. https://doi.org/10.2135/ cropsci2006.10.0687.

García-Lara, S., Vargas, M., Khairallah, M.M., Bergvinson, D.., 2009. Mapping of QTL associated with maize weevil resistance in tropical maize. Crop Sci. 49 139-149. https://doi.org/10.2135/cropsci2007.06.0326.

García-Lara, S., Burt, A.J., Arnason, J.T., Bergvinson, D.J., 2010a. QTL mapping of grain compounds associated with maize weevil resistance in tropical maize. Crop Sci. 51, 23-34. https://doi.org/10.2135/cropsci2009.07.0415.

García-Lara, S., Bergvinson, D.J., 2013. Identification of maize landraces with high level of resistance to storage pests Sitophilus zeamais Motschulsky and Prostephanus truncatus Horn in Latin America. Rev. Fitotec. Mex. 36, 347-356.

García-Lara, S., Chuck-Hernandez, C., Serna-Saldivar, S.O., 2013a. Comparison of the processing and quality of tortillas produced from larger grain borer Prostephanus truncatus (Horn.) resistant and susceptible maize genotypes. J. Stored Prod. Res. 55, 99-105. https://doi.org/10.1016/j.jspr.2013.09.002.

García-Lara, S., Bergvinson, D.J., 2014. Phytochemical and nutraceutical changes during recurrent selection for storage pest resistance in tropical maize. Crop Sci. 54, 2423. https://doi.org/10.2135/cropsci2014.03.0223.

García-Lara, S., Bergvinson, D.J., Burt, A.J., Ramputh, A.I., Díaz-Pontones, D.M. Arnason, J.T., 2004. The role of pericarp cell wall components in maize weevil resistance. Crop Sci. 44, 1546-1552. https://doi.org/10.2135/ cropsci2004.1546.

García-Lara, S., Burt, A.J., Arnason, J.T., Bergvinson, D.J., 2010b. QTL mapping of tropical maize grain components associated with maize weevil resistance. Crop Sci. 50, 815-825. https://doi.org/10.2135/cropsci2009.07.0415.

García-Lara, S., Burt, A.J., Serratos, J.A., Pontones, D.M.D., Arnason, J.T. Bergvinson, D.J., 2003. Defensas naturales en el grano de Maíz al ataque de Sitophilus zeamais (Motsch, Coleoptera: Curculionidae): mecanismos y bases de la resistencia. Rev. Educ. Bioquímica (REB, Mex.) 22, 138-145. Available at: http://www.uacj.mx/ICB/RedCIB/REB/2003/09/REB-3_DEFENSAS.pdf.

García-Lara, S., Ortíz-Islas, S., Villers, P., 2013b. Portable hermetic storage bag resistant to Prostephanus truncatus, Rhyzopertha Dominica, and Callosobruchus maculatus. J. Stored Prod. Res. 54, 23-25. https://doi.org/10.1016 j.jspr.2013.04.001.

García-Lara, S., Serna-Saldivar, S.O., 2016. Insect pests. Ency. of Food and Health 3 , 432-436. https://doi.org/10.1016/B978-0-12-384947-2.00396-2.

Gaytán-Martínez, M., Figueroa-Cárdenas, J.D., Reyes-Vega, M.L., Rincón-Sánchez, F. 2006. Microstructure of starch granule related to kernel hardness in corn. Rev. Fitotec. Mex. 29, 135-139.

Gitonga, Z.M., De Groote, H., Kassie, M., Tefera, T., 2013. Impact of metal silos on households' maize storage, storage losses and food security: an application of a propensity score matching. Food Pol. 43, 44-55. https://doi.org/10.1016/ j.foodpol.2013.08.005.

Hill, M.G., Hill, M.G., Nang'ayo, F.L.O., Wright, D.J., 2003. Biological control of the larger grain borer Prostephanus truncatus (Coleoptera: Bostrichidae) in Kenya using a predatory beetle Teretrius nigrescens (Coleoptera: histeridae). Bull. Entomol. Res. 93, 299-306. https://doi.org/10.1079/BER2003247. 
Hodges, R.J., 1986. The biology and control of Prostephanus truncatus (Horn) (Coleoptera: Bostrichidae)-A destructive storage pest with an increasing range. J. Stored Prod. Res. 22, 1-14. https://doi.org/10.1016/0022-474X(86)90040-8.

Hogenhout, S.A., Bos, J.I.B., 2011. Effector proteins that modulate plant-insect interactions. Curr. Opin. Plant Biol. 14, 422-428. https://doi.org/10.1016/ j.pbi.2011.05.003.

Holland, N., Holland, D., Helentjaris, T., Dhugga, K.S., Xoconostle-Cazares, B., Delmer, D.P., 2000. A comparative analysis of the plant cellulose synthase (CesA) gene family. Plant Physiol. 123, 1313-1324.

Hood, E.E., Hood, K.R., Fritz, S.E., 1991. Hydroxyproline-rich glycoproteins in cell walls of pericarp from maize. Plant Sci. 79, 13-22. https://doi.org/10.1016/01689452(91)90063-E.

Huang, F., Andow, D.A., Buschman, L.L., 2011. Success of the high-dose/refuge resistance management strategy after 15 years of Bt crop use in North America. Entomol. Exp. Appl. 140, 1-16. https://doi.org/10.1111/j.1570-7458.2011.01138.x.

Ignjatović-Micić, D., Ristić, D., Babić, V., Andjelković, V., Marković, K., Vančetović, J. 2013. Genetic assessment of maize landraces from former Yugoslavia. Genetika 45, 405-417. https://doi.org/10.2298/GENSR1302405I.

Iiyama, K., Lam, T., Stone, B.A., 1994. Covalent cross-links in the cell wall. Plant Physiol. 104, 315-320. https://doi.org/10.1104/pp.104.2.315.

Jermy, T., 1984. Evolution of insect/host plant relationships. Source Am. Nat. Am. Nat. 124, 609-630. https://doi.org/10.1086/284302.

Khan, Z., 1997. A review of entomological techniques and methods used to determine mechanisms and bases of stem borer resistance in maize. In: Mihm, J.A (Ed.), Insect Resistance Maize: Recent Advances and Utilization; Proceeding of an International Symposium Held at CIMMYT. CIMMYT, Mexico D.F., Mexico.

Krakowsky, M.D., Lee, M.. Holland, J.B., 2007. Genotypic correlation and multivariate QTL analyses for cell wall components and resistance to stalk tunneling by the European corn borer in maize. Crop Sci. 47, 485-490.

Kramer, K.J., Morgan, T.D., Throne, J.E., Dowell, F.E., Bailey, M., Howard, J.A., 2000 Transgenic avidin maize is resistant to storage insect pests. Nat. Biotechnol. 18 670-674. https://doi.org/10.1038/76531.

Kumar, D., Kalita, P., 2017. Reducing postharvest losses during storage of grain crops to strengthen food security in developing countries. Foods 6, 8. https://doi.org/ $10.3390 /$ foods6010008.

Lamb, R., Smith, M., Wise, I., McKenzie, R., 2016. Resistance to wheat midge (Diptera: cecidomyiidae) in winter wheat and the origins of resistance in spring wheat (Poaceae). Can. Entomol. 148 (2), 229-238. https://doi.org/10.4039/ tce.2015.48.

Landry, J., Delhaye, S., Damerval, C., 2004. Protein distribution pattern in floury and vitreous endosperm of maize grain. Cereal Chem. 81, 153-158. https://doi.org 10.1094/CCHEM.2004.81.2.153.

Lesk, C., Rowhani, P., Ramankutty, N., 2016. Influence of extreme weather disasters on global crop production. Nature 529, 84-87. https://doi.org/10.1038/ nature 16467.

Lopes, M.A., Larkins, B.A., 1993. Endosperm origin, development, and function. Plant Cell 5, 1383-1399. https://doi.org/10.1105/tpc.5.10.1383.

López-Castillo, L.M., López-Arciniega, J.A.I., Guerrero-Rangel, A., ValdésRodríguez, S., Brieba, L.G., García-Lara, S., Winkler, R., 2015. Identification of B6T173 (ZmPrx35) as the prevailing peroxidase in highly insect-resistant maize (Zea mays, p84C3) kernels by activity-directed purification. Front. Plant Sci. 6 1-13. https://doi.org/10.3389/fpls.2015.00670.

López-Castillo, L.M., Díaz Flores-Rivera, M.F., Winkler, R., García-Lara, S., 2018. Increase of peroxidase activity in tropical maize after recurrent selection to storage pest resistance. J. Stored Prod. Res. 75, 47-55. https://doi.org/10.1016/ j.jspr.2017.11.007.

Mason, L.J., McDonough, M., 2012. Biology, behavior, and ecology of stored grain and legume insects. In: Hagstrum, D.W., et al. (Eds.), Stored Product Protection. Kansas State University, pp. 7-20.

Mestres, C., Matencio, F., 1996. Biochemical basis of kernel milling characteristics and endosperm vitreousness of maize. J. Cereal. Sci. 24, 283-290. https:/ doi.org/10.1006/jcrs.1996.0060.

Meyer, J.D.F., Snook, M.E., Houchins, K.E., Rector, B.G., Widstrom, N.W., McMullen, M.D., 2007. Quantitative trait loci for maysin synthesis in maize (Zed mays L.) lines selected for high silk maysin content. Theor. Appl. Genet. 115 $119-128$

Midega, C.A.O., Murage, A.W., Pittchar, J.O., Khan, Z.R., 2016. Managing storage pests of maize: farmers' knowledge, perceptions and practices in western Kenya. Crop Protect. 90, 142-149. https://doi.org/10.1016/j.cropro.2016.08.033.

Mihm, J., 1985. Breeding for host plant resistance to maize stem-borers. Insect Sci Appl. 6 (3), 369-377. https://doi.org/10.1017/S1742758400004653.

Mikami, A.Y., Carpentieri-Pípolo, V., Ventura, M.U., 2012. Resistance of maize landraces to the maize weevil Sitophilus zeamais Motsch. (Coleoptera: Curculionidae). Neotrop. Entomol. 41, 404-408. https://doi.org/10.1007/s13744-0120054-8.

Mlambo, S., Mvumi, B.M., Stathers, T., Mubayiwa, M., Nyabako, T., 2017. Field efficacy of hermetic and other maize grain storage options under smallholder farmer management. Crop Protect. 98, 198-210. https://doi.org/10.1016 j.cropro.2017.04.001.

Mohandass, S., Arthur, F.H., Zhu, K.Y., Throne, J.E., 2007. Biology and management of Plodia interpunctella (Lepidoptera: Pyralidae) in stored products. J. Stored Prod. Res. 43, 302-311. https://doi.org/10.1016/j.jspr.2006.08.002.

Mwololo, J.K., Mugo, S., Okori, P., Tefera, T., Otim, M., Munyiri, S.W., 2012. Sources of resistance to the maize weevil Sitophilus zeamais in tropical maize. J. Agric. Sci. 4, 206-215. https://doi.org/10.5539/jas.v4n11p206.
Mwololo, J.K., Mugo, S., Tefera, T., Sw, M., Box, P.O., 2013. Evaluation of traits of resistance to postharvest insect pests in tropical maize. Intl. J. Agric. Crop Sci. 6, 926-933.

Narváez-González, E.D., Figueroa-Cárdenas, J.D.D., Taba, S., Castaño-Tostado, E., Martínez-Peniche, R.Á., Rincón-Sánchez, F., 2006. Relationships between the microstructure, physical features, and chemical composition of different maize accessions from Latin America. Cereal Chem. 83, 595-604. https://doi.org/ 10.1094/CC-83-0595.

Ndolo, V.U., Beta, T., Fulcher, R.G., 2013. Ferulic acid fluorescence intensity profiles and concentration measured by HPLC in pigmented and non-pigmented cereals. FRIN 52, 109-118. https://doi.org/10.1016/j.foodres.2013.02.031.

Ng'ang'a, J., Mutungi, C., Imathiu, S.M., Affognon, H., 2016. Low permeability triple-layer plastic bags prevent losses of maize caused by insects in rural onfarm stores. Food Secur. 8, 621-633. https://doi.org/10.1007/s12571-0160567-9.

Nwosu, L.C., Adedire, C.O., Ogunwolu, E.O., 2015. Screening for New Sources of Resistance to Sitophilus Zeamais Motschulsky (Coleoptera: Curculionidae) Infestation in Stored Maize Genotypes, p. 4.

Oerke, E.-C., 2006. Crop losses to pests. J. Agric. Sci. 144, 31-43. https://doi.org/10. $1017 /$ S0021859605005708.

Oloyede-Kamiyo, Q.O., Adetumbi, J.A., 2017. Relationship between seed physical traits and maize weevil (Sitophilus zeamais) damage parameters in selected Quality Protein Maize (QPM) varieties. J. Stored Prod. Res. 73, 42-46. https:// doi.org/10.1016/j.jspr.2017.06.003.

Piesik, D., Wenda-Piesik, A., 2015. Sitophilus granarius responses to blends of five groups of cereal kernels and one group of plant volatiles. J. Stored Prod. Res. 63 , 63-66. https://doi.org/10.1016/j.jspr.2015.05.007.

Popp, J., Peto, K., Nagy, J., 2013. Pesticide productivity and food security. A review. Agron. Sustain. Dev. 33, 243-255. https://doi.org/10.1007/s13593-012-0105-x.

Rausher, M.D., 2001. Co-evolution and plant resistance to natural enemies. Nature $411,857-864$.

Robutti, J., Borras, F., Eyherabide, G., 1997. Zein Composition of mechanically separated coarse and fine protions of maize kernels. Cereal Chem. 74, 75-78.

Rodríguez-Kessler, M. Alpuche-Solís, A.G., Ruiz, O.A., Jiménez-Bremont, J.F. 2006 Effect of salt stress on the regulation of maize (Zea mays L.) genes involved in polyamine biosynthesis. Plant Growth Regul. 48, 175-185.

Ronald, P., 2011. Plant genetics, sustainable agriculture and global food security. Genetics 188, 11-20. https://doi.org/10.1534/genetics.111.128553.

Rosegrant, M.W., Ringler, C., Sulser, T.B., Ewing, M., Palazzo, A., Zhu, T., et al., 2009. Agriculture and Food Security under Global Change: Prospects for 2025/2050. South Asia.

Sallam, M.N., 1999. Insect damage. Damage on post-harvest. In: Mejia, D., Lewis, B. (Eds.), InPho - Post-harvest Compendium. Food and Agriculture Organization of the United Nations, Nairobi, Kenya, p. 37.

Santiago, R., Barros-Rios, J., Malvar, R.A., 2013. Impact of cell wall composition on maize resistance to pests and diseases. Int. J. Mol. Sci. 14, 6960-6980. https:// doi.org/10.3390/ijms14046960.

Saulnier, L., Thibault, J.F., 1999. Ferulic acid and diferulic acids as components of sugar-beet pectins and maize bran heteroxylans. J. Sci. Food Agric. 79, 396-402. https://doi.org/10.1002/(SICI)1097-0010(19990301)79:3<396::AIDJSFA262>3.0.CO $2-\mathrm{B}$

Schöller, M., Flinn, P.W., 2000. Parasitoids and predators. In: Subramanyam, B. Hagstrum, D.W. (Eds.), Alternatives to Pesticides in Stored-product IPM. Kluwer Academic Publishers, Boston, Massachusetts, USA, pp. 229-271.

Sen, A., Bergvinson, D., Miller, S.S., Atkinson, J., Fulcher, R.G., Arnason, J.T., 1994. Distribution and microchemical detection of phenolic acids, flavonoids, and phenolic acid amides in maize kernels. J. Agric. Food Chem. 42, 1879-1883. https://doi.org/10.1021/jf00045a009.

Serna-Saldivar, S.O., García-Lara, S., 2016. Storage. Ency. of Food and Health 3 712-717. https://doi.org/10.1016/B978-0-12-384947-2.00129-X.

Serratos, A., Arnason, J.T., Nozzolillo, C., Lambert, J.D.H., Philogne, B.J.R., Fulcher, G., Davidson, K., Peacock, L., Atkinson, J., Morand, P., 1987. Factors contributing to resistance of exotic maize populations to maize weevil, Sitophilus zeamais. J. Chem. Ecol. 13, 751-762. https://doi.org/10.1007/BF01020157.

Serratos, J.A., Arnason, J.T., Blanco-Labra, A., Mihm, J.A., 1997. Genetic of maize grain resistance to maize weevil. In: Mihm, J.A. (Ed.), Insect Resistance Maize: Recent Advances and Utilization; Proceeding of an International Symposium Held at CIMMYT. CIMMYT, Mexico D.F., Mexico, pp. 132-138.

Sharma, H.C., Ortiz, R., 2002. Host plant resistance to insects: an eco-friendly approach for pest management and environment conservation. J. Environ. Biol. 23, 111-135.

Shiferaw, B., Prasanna, B.M., Hellin, J., Bänziger, M., 2011. Crops that feed the world 6. Past successes and future challenges to the role played by maize in global food security. Food Secur. 3, 307-327. https://doi.org/10.1007/s12571-0110140-5.

Simms, E.L., Fritz, R.S., 1990. The ecology and evolution of host-plant resistance to insects. Trends Ecol. Evol. 5, 356-360. https://doi.org/10.1016/0169-5347(90) 90094-T.

Siwale, J., Mbata, K., Microbert, J., Lungu, D., 2009. Comparative resistance of improved maize genotypes and landraces to maize weevil. Afr. Crop Sci. J. 17, $1-16$

Smith, C., 1997. An overview of the mechanisms and bases of insect resistance in maize. In: Mihm, J.A. (Ed.), Insect Resistance Maize: Recent Advances and Utilization; Proceeding of an International Symposium Held at CIMMYT. CIMMYT, Mexico D.F., Mexico. 
Sori, W., Ayana, A., 2012. Storage pests of maize and their status in Jimma Zone, Ethiopia. Afr. J. Agric. Res. 7, 4056-4060. https://doi.org/10.5897/AJAR11.1123.

Tefera, T., 2012. Post-harvest losses in African maize in the face of increasing food shortage. Food Secur. 4, 267-277. https://doi.org/10.1007/s12571-012-0182-3.

Tefera, T., Kanampiu, F., De Groote, H., Hellin, J., Mugo, S., Kimenju, S., et al., 2011. The metal silo: an effective grain storage technology for reducing post-harvest insect and pathogen losses in maize while improving smallholder farmers' food security in developing countries. Crop Protect. 30, 240-245. https://doi.org/ 10.1016/j.cropro.2010.11.015.

Tefera, T., Mugo, S., Beyene, Y., 2016. Developing and deploying insect resistant maize varieties to reduce pre-and post-harvest food losses in Africa. Food Secur. 8, 211-220. https://doi.org/10.1007/s12571-015-0537-7.

Tefera, T., Mugo, S., Beyene, Y., Karaya, H., Gakunga, J., Demissie, G., 2013. Postharvest insect pest and foliar disease resistance and agronomic performance of new maize hybrids in East Africa. Int. J. Plant Breed. Genet. 7, 92-104. https:// doi.org/10.3923/ijpbg.2013.92.104.

Tefera, T., Mugo, S., Tende, R., Likhayo, P., 2011b. Methods of Screening Maize for Resistance to Stem Borers and Post-harvest Insect Pests. CIMMYT, Nairobi, Kenya.

Thomas, M., Waage, J., 1996. Integration of Biological Control and Host-plant Resistance Breeding: a Scientific and Literature Review.

Thompson, J.N., 1999. Specific hypotheses on the geographic mosaic of coevolution. Am. Nat. 153, S1-S14. https://doi.org/10.1086/303208.
Tipping, P.W., Cornelius, P.L., Legg, D.E., Poneleit, C.G., Rodriguez, J.G., 1989. Inherence of resistance in whole kernel maize to oviposition by the maize weevil (Coleoptera: Curculionidae). J. Econ. Entomol. 82, 1466, 1460.

Trematerra, P., 2013. Aspects related to decision support tools and integrated pest management in food chains. Food Contr. 34, 733-742. https://doi.org/10.1016 j.foodcont.2013.06.020.

Trematerra, P., Ianiro, R., Athanassiou, C.G., Kavallieratos, N.G., 2013. Behaviora responses of Sitophilus zeamais Motschulsky adults to conditioned grain kernels. J. Stored Prod. Res. 53, 77-81. https://doi.org/10.1016/j.jspr.2013.02.005.

Trematerra, P., Valente, A., Athanassiou, C.G., Kavallieratos, N.G., 2007. Kernel-kerne interactions and behavioral responses of Sitophilus zeamais Motschulsky (Coleoptera: Curculionidae). Appl. Entomol. Zool. 42, 129-135. https://doi.org/ 10.1303/aez.2007.129.

Winkler, R., García-Lara, S., 2010. Activity-directed identification of maize kernel peroxidases associated with postharvest insect resistance. Mol. Biosyst. 6, 1810-1812. https://doi.org/10.1039/c003112g.

Wiseman, B.R., 1985. Types and mechanisms of host plant resistance to insect attack. Insect Sci. its Appl. 6, 239-242. https://doi.org/10.1017/ S1742758400004483.

Wiseman, B.R., 1994. Plant resistance to insects in cotton. Plant Dis. 78, 927-932. https://doi.org/10.1094/PD-78-0927.

Yencho, G.C., Cohen, M.B., Byrne, P.F., 2000. Applications of tagging and mapping insect resistance loci in plants. Annu. Rev. Entomol. 45, 393-422. 